\title{
STATIC VOLUME-PRESSURE RELATIONS OF EXCISED LUNGS OF INFANTS WITH HYALINE MEMBRANE DISEASE, NEWBORN AND STILLBORN INFANTS
}

\author{
By IRWIN GRIBETZ,* N. R. FRANK † AND MARY ELLEN AVERY \\ (From the Department of Physiology, Harvard School of Public Health, Department of \\ Pediatrics, Harvard Medical School, and Boston Lying-in Hospital, \\ Boston, Mass.)
}

(Submitted for publication June 15, 1959; accepted August 14, 1959)

The clinical features of hyaline membrane disease have been reviewed recently $(1,2)$. When the disease is fatal the lungs at autopsy are usually grossly atelectatic, suggesting the appearance of liver. Microscopically, this atelectasis is seen to be patchy and widespread; scattered through the lungs are dilated terminal bronchioles and alveolar ducts that are lined with an eosinophilic membrane.

The significance of the membrane during life is uncertain. Behrle, Gibson and Miller (3) demonstrated at autopsy that the expansion of lungs of infants was impeded by the membrane. More recently, Craig, Fenton and Gitlin (4) showed from latex casts of the airways that the membrane may cause obstruction. But Gruenwald (5) has taken the view that the membrane may be only "a secondary phenomenon that appears in a previously diseased lung." $\mathrm{He}$ has stressed instead the greater importance of the atelectasis to which these lungs appear vulnerable.

Our object was to study the static elastic behavior of lungs containing hyaline membranes. For this purpose static volume-pressure relations of lungs from three sources were compared: newborn infants with a histologic diagnosis of hyaline membrane disease, newborn infants dying of other causes, and stillborn infants. On the basis of these measurements, estimates were made of the differences in functional residual capacity (FRC) and pulmonary compliance that might have pre-

\footnotetext{
* This work was done during tenure of a Fellowship from The National Foundation. Present address: Army Chemical Center, Md.

†This study was aided by a grant from The $\mathrm{Na}$ tional Foundation.

$\ddagger$ This work was supported in part by a special Traineeship (BT259) from the National Institute of Neurological Diseases and Blindness, United States Public Health Service.
}

vailed during life among the first two groups; these estimates were compared with the few data available on living infants $(6,7)$. The factors that may be responsible for changes in elastic behavior of lungs with hyaline membrane disease will be discussed.

\section{METHODS}

The material included 10 lungs from newborn infants with hyaline membrane disease, five lungs from stillborn infants and five lungs from infants who died within the first four days of life. The right or left lung alone was used in each experiment, the other side being reserved for examination by the pathologist. All measurements were made within 48 hours of the time of death. Before study the tissue was kept at temperatures of about 5 to $10^{\circ} \mathrm{C}$. to prevent autolysis.

The preparation is shown schematically in Figure 1 . The lung was suspended from a cannula tied into the main bronchus. As the burette was elevated fluid flowed into the intermediate bottle displacing gas into the lung. The difference between levels of fluid in the burette and the bottle represented the distending pressure applied to the lung. This pressure was read from a water-filled manometer connected to the bronchial cannula. The

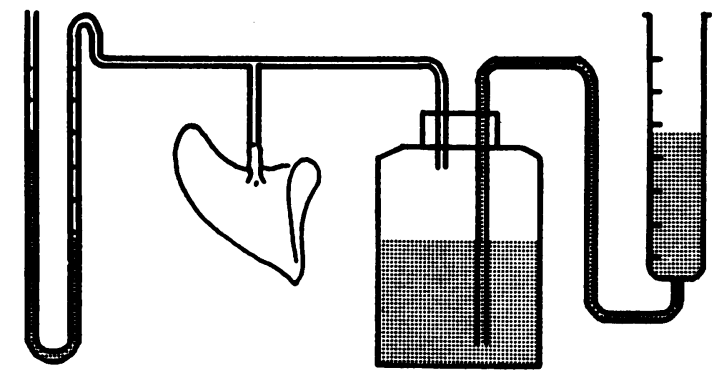

Fig. 1. Apparatus for Inflation and Deflation

Inflation and deflation were carried out in fixed steps of pressure. Airway pressure (the difference in level between the burette and the intermediate bottle) was measured by means of the fluid-filled manometer on the left. Correction was made for compression of the gas in the intermediate bottle and the tubing leading to the lung. 
volume of air entering the lung was read directly from the burette; correction was made for compression of gas in the system by the distending pressure. The lung was inflated in fixed steps of pressure until a peak level of $35 \mathrm{~cm} . \mathrm{H}_{2} \mathrm{O}$ was reached. The lung was then deflated, usually in the same steps, until zero airway pressure was reached. During inflation and deflation two minutes were allowed for changes of volume at each pressure; at the end of this time equilibrium was virtually established.

The lung was weighed at the outset; its volume was then measured by displacement of fluid before and after each run. Some of the lungs from newborn infants contained a small amount of gas at the outset. This volume of gas was estimated, assuming that the specific gravity of the tissue was 1.065 (8). To correct for leaks that may have occurred during the procedure, the change in volume of the lung following each run was compared with the change in level of fluid in the burette; when the loss of fluid from the burette was greater than the increase in volume of the lung, the discrepancy was ascribed to a leak. A correction was made assuming that the rate of leakage was directly proportional to airway pressure. With one exception, the leaks represented less than 12 per cent of the peak volume in the lung; for the one exception, the leak equaled 28 per cent.

\section{RESULTS}

The weight of the infants and of the lungs, the duration of extrauterine life, and the diagnoses are listed in Tables I through III. The three groups showed no significant differences in body weight or lung weight. To calculate the ratio of lung-tobody weight, the assumption was made that the right and left lungs, only one of which was available for study, were equal in weight. Had the right lung represented as much as 60 per cent of the total weight of the lungs, the change in values for this ratio would have been negligible.
TABLE I

Physical characteristics of five stillborn infants having diagnosis of intrauterine asphyxia

\begin{tabular}{cccccc}
\hline \hline & & $\begin{array}{c}\text { Body } \\
\text { weight* }\end{array}$ & $\begin{array}{c}\text { Lung } \\
\text { studied }\end{array}$ & $\begin{array}{c}\text { Lung } \\
\text { weight }\end{array}$ & $\begin{array}{c}\text { Lung weight } \\
\text { Body weight }\end{array} \times 100$ \\
\hline & & $K g$. & & $G m$. & $\%$ \\
1 & M & 0.67 & R & 6 & 1.8 \\
2 & M & 2.20 & L & 22 & 2.0 \\
3 & M & 2.25 & L & 25 & 2.2 \\
4 & F & 2.62 & L & 18 & 1.4 \\
5 & M & 3.07 & L & 28 & 1.8 \\
Mean & & 2.16 & & 20 & 1.8 \\
\hline
\end{tabular}

* At autopsy.

† Weight of single lung which was studied.

$\ddagger$ Based on estimated weight of entire lung (see text).

At a maximal distending pressure of $35 \mathrm{~cm} . \mathrm{H}_{2} \mathrm{O}$ the lungs of newborn and stillborn infants appeared fully inflated, whereas inflation of the lungs with hyaline membranes was incomplete. The surface of the latter lungs showed multiple lobulations surrounded by depressed, unexpanded segments of tissue. Photographs of sections from a lung with hyaline membranes are shown in Figure $2 \mathrm{~A}$ through D). Figure 3 and Table IV compare the average static volume-pressure relations of the lungs of the three groups of infants. To permit comparison of lungs of different size, volume was expressed as milliliters of gas per gram of tissue. At a pressure of $35 \mathrm{~cm} . \mathrm{H}_{2} \mathrm{O}$, the lungs of newborn infants contained about four times as much gas per unit of weight as the lungs of infants with hyaline membrane disease. The value for lungs of stillborn infants was intermediate. These differences were roughly similar over most of the volumepressure curve.

TABLE II

Extrauterine age, physical characteristics and diagnosis of five newborn infants

\begin{tabular}{|c|c|c|c|c|c|c|c|}
\hline No. & Sex & Age & $\underset{\text { weight* }}{\text { Body }}$ & $\begin{array}{l}\text { Lung } \\
\text { studied }\end{array}$ & $\underset{\text { weight }}{\text { Lung }}$ & $\frac{\text { Lung weight } \ddagger}{\text { Body weight }} \times 100$ & Diagnosis \\
\hline & & hrs. & $K g$ & & $G m$. & $\%$ & \\
\hline 1 & M & 57 & 0.88 & $\mathrm{R}$ & 13 & 3.0 & Prematurity \\
\hline 2 & $\mathrm{~F}$ & 70 & 1.60 & $\mathrm{R}$ & 18 & 2.2 & Pneumonia \\
\hline 3 & $\mathrm{~F}$ & 72 & 1.65 & $\mathrm{R}$ & 22 & 2.7 & Pneumonia \\
\hline 4 & $\mathrm{M}$ & 24 & 2.44 & $\mathrm{~L}$ & 23 & 1.9 & Intraventricular \\
\hline 5 & M & 72 & 2.56 & $\mathrm{~L}$ & 18 & 1.4 & Hydronephrosis \\
\hline Mean & & & 1.82 & & 19 & 2.0 & \\
\hline
\end{tabular}

* At autopsy.

$\dagger$ Weight of single lung which was studied.

$\ddagger$ Based on estimated weight of entire lung (see text). 
TABLE III

Extrauterine age and physical characteristics of 10 infants having hyaline membrane disease

\begin{tabular}{|c|c|c|c|c|c|c|}
\hline No. & Sex & Age & $\begin{array}{c}\text { Body } \\
\text { weight* }\end{array}$ & $\begin{array}{l}\text { Lung } \\
\text { studied }\end{array}$ & $\begin{array}{c}\text { Lung } \\
\text { weight } \dagger\end{array}$ & $\frac{\text { Lung weight } \ddagger}{\text { Body weight }} \times 100$ \\
\hline $\begin{array}{r}1 \\
2 \\
3 \\
4 \\
5 \\
6 \\
7 \\
8 \\
9 \\
10\end{array}$ & $\begin{array}{l}\text { M } \\
\mathbf{M} \\
\mathbf{M} \\
\mathbf{M} \\
\mathbf{M} \\
\mathbf{M} \\
\mathbf{M} \\
\mathrm{F} \\
\mathbf{M} \\
\mathbf{M}\end{array}$ & $\begin{array}{r}\text { hrs. } \\
10 \\
24 \\
22 \\
48 \\
7 \\
29 \\
20 \\
36 \\
70 \\
43\end{array}$ & $\begin{array}{c}K g . \\
0.85 \\
1.85 \\
1.95 \\
2.10 \\
2.35 \\
2.38 \\
2.40 \\
2.60 \\
2.80 \\
3.00\end{array}$ & $\begin{array}{l}\text { R } \\
\text { R } \\
\text { L } \\
\text { L } \\
\text { R } \\
\text { L } \\
\text { L } \\
\text { L } \\
\text { R } \\
\text { R }\end{array}$ & $\begin{array}{r}\text { Gm. } \\
10 \\
19 \\
17 \\
25 \\
26 \\
24 \\
21 \\
29 \\
30 \\
26\end{array}$ & $\begin{array}{c}\% \\
2.4 \\
2.0 \\
1.7 \\
2.4 \\
2.2 \\
2.0 \\
1.8 \\
2.2 \\
2.1 \\
1.7\end{array}$ \\
\hline Mean & & & 2.29 & & 23 & 2.0 \\
\hline
\end{tabular}

* At autopsy.

$\dagger$ Weight of single lung which was studied.

$\ddagger$ Based on estimated weight of entire lung (see text).

\section{DISCUSSION}

The study has shown that excised lungs containing hyaline membranes contain less gas per unit of weight than do the lungs of newborn or stillborn infants of similar size. This is true for all inflating pressures between 0 and $35 \mathrm{~cm} . \mathrm{H}_{2} \mathrm{O}$. As a corollary, the slope of the volume-pressure curve of the lungs with hyaline membranes is reduced over virtually the entire range of volume. That similar conclusions may be inferred about these lungs during life is suggested by the work of McIlroy and Christie (9) who found that the distensibility of human lungs was of the "same order as that found during life" in specimens studied up to 72 hours after death. In our study the upper limit of time following death was 48 hours.

There is evidence suggesting that the lungs of infants and children may become more distensible (contain more gas per unit of lung weight for a given distending pressure) with advancing age $(10,11)$. It is therefore important to stress that no significant difference in gestational age was present among the three groups, using body weight as an index of age.

The lungs of newborn infants, in spite of the presence of pneumonia in two specimens, were generally about twice as distensible as those of stillborn infants (Figure 1, Table IV). The reason for this difference is not clear; it was not revealed by the pathologist's examination of the tissue.
We have given emphasis to volume-pressure relations during deflation following application of a fixed peak distending pressure. Such measurements are less variable than measurements made during inflation, especially if inflation proceeds from the passively collapsed state. In the latter circumstance the presence of fluid in the airways (12), the configuration of the airways (13), and to some extent the interval of time following death (11) may affect the volume-pressure relations.

\section{FRC and associated transpulmonary pressure}

Estimates were made of the average differences in FRC and compliance that might have been present during life between the infants with hyaline membrane disease and the newborn infants. To do this, the data in Figure 3 were replotted in Figure 4 with the vertical axis expressing absolute volume without relation to the weight of the lungs and the horizontal axis expressing transpulmonary pressure. Such estimates have no application to stillborn infants and were not made.

Berglund and Karlberg (6) reported measurements of FRC in healthy newborn infants. Their subjects with one exception were heavier than the newborn infants in our study. Based on the correlation they found between FRC and birth weight, the average FRC of our newborn infants without hyaline membrane disease would be expected to fall between 60 and $70 \mathrm{ml}$. For this range of

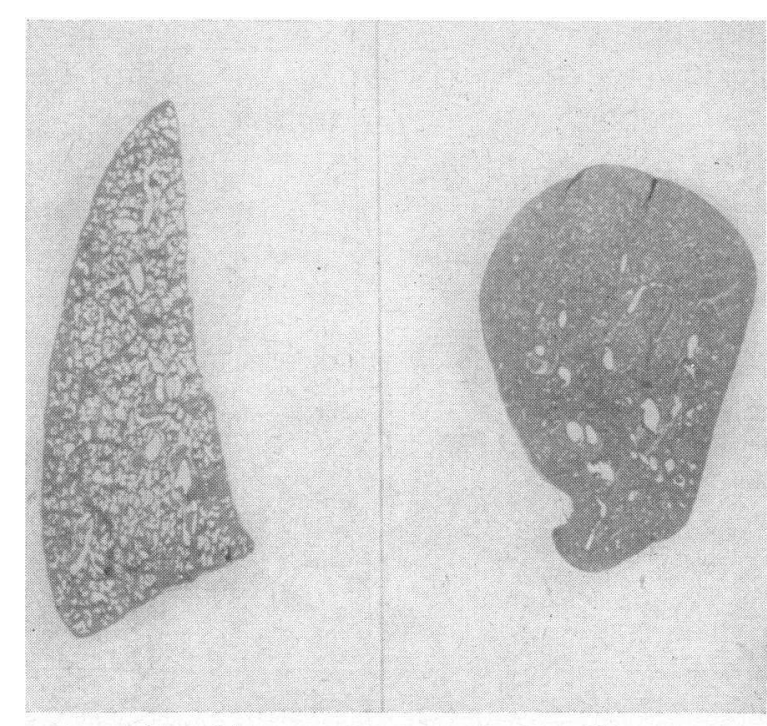

$$
\begin{array}{ll}
\text { FIG. 2A } & \text { FIG. 2B }
\end{array}
$$




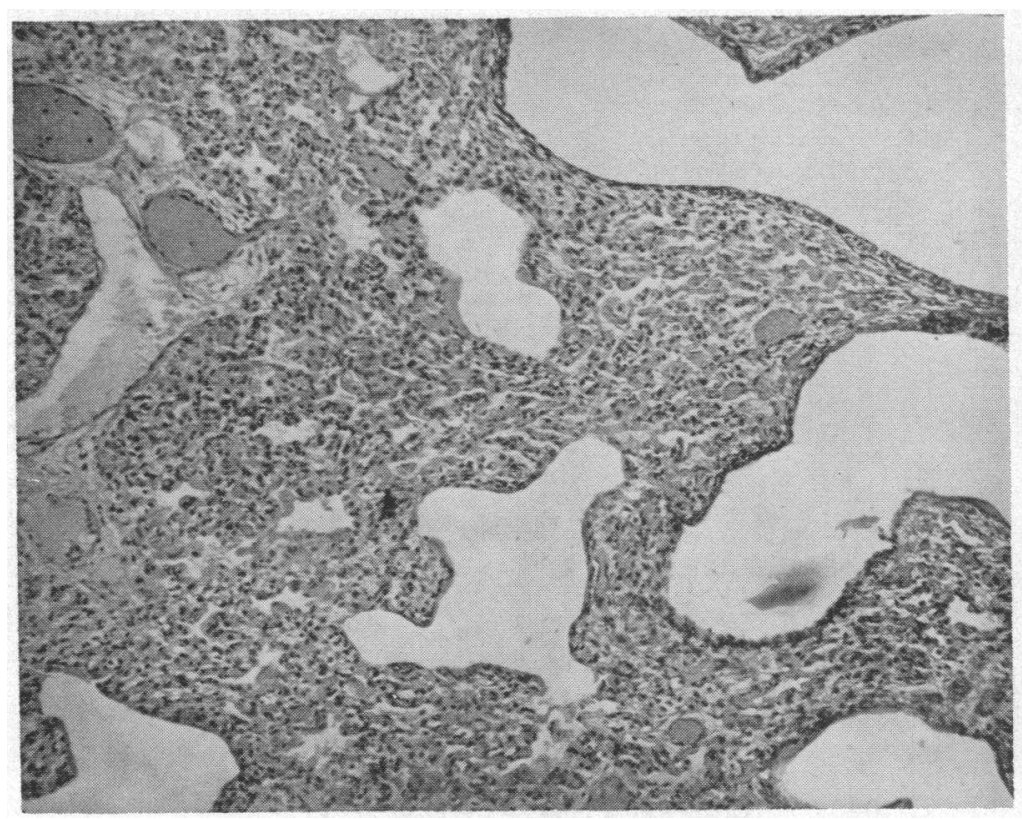

Fig. 2C

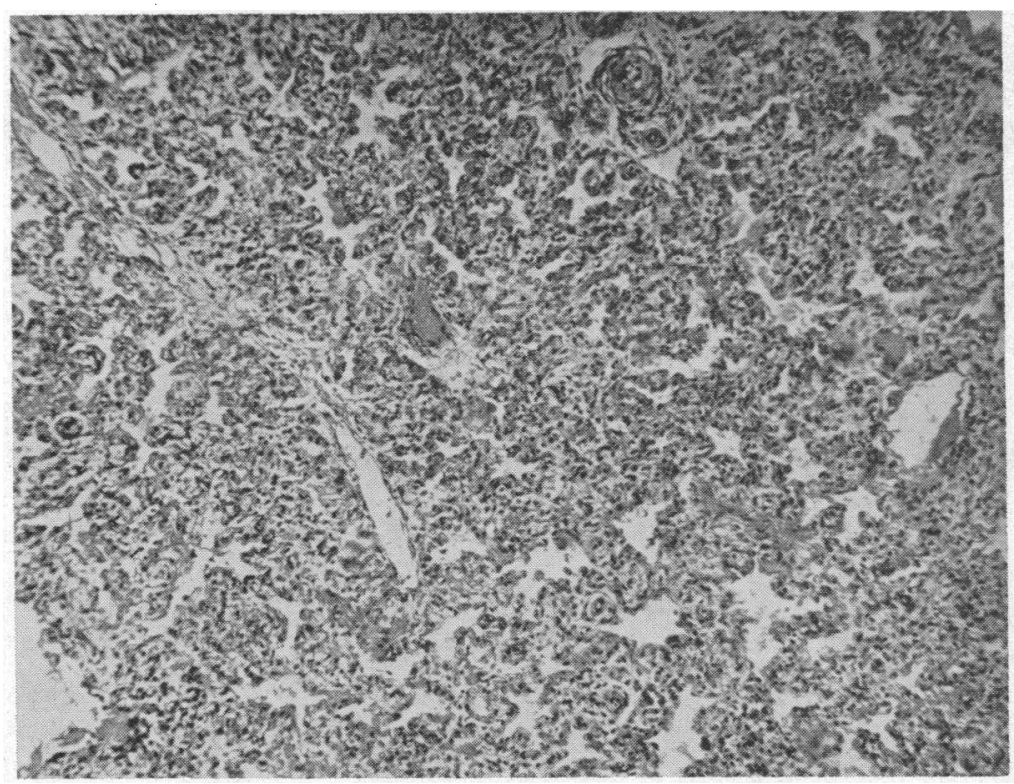

FIG. 2D

Fig. 2. Section of Lung Containing Hyaline Membranes from an Infant Weighing $1.67 \mathrm{KG}$.

A shows the specimen inflated with air to a pressure of about $35 \mathrm{~cm} . \mathrm{H}_{2} \mathrm{O}$ and fixed with Bouin's solution; B shows a section from the same lung fixed at atmospheric pressure; $\mathrm{C}$ is a photomicrograph of the lung in A ( $140 \times$ magnification). Note the irregular filling: some areas are overdistended and others are unopened. $D$ is a photomicrograph of the lung in $B$ $(140 \times$ magnification $)$. Note the widespread atelectasis. 
TABLE IV

Static volume-pressure characteristics during deflation of excised lungs of stillborn infants, newborn infants, and infants dying of hyaline membrane disease

\begin{tabular}{|c|c|c|c|c|c|c|c|c|c|}
\hline & \multirow[b]{2}{*}{ No. } & \multirow{2}{*}{$\begin{array}{l}\text { Body } \\
\text { weight* }\end{array}$} & \multicolumn{7}{|c|}{$\begin{array}{l}\text { Volume } \\
\text { Pressure }\left(\mathrm{cm} . \mathrm{H}_{2} \mathrm{O}\right)\end{array}$} \\
\hline & & & 35 & 25 & 15 & 10 & 5 & 2.5 & $\mathbf{0}$ \\
\hline Stillborn & $\begin{array}{l}1 \\
2 \\
3 \\
4 \\
5\end{array}$ & $\begin{array}{c}K g . \\
0.67 \\
2.20 \\
2.25 \\
2.62 \\
3.07\end{array}$ & $\begin{array}{l}1.3 \\
1.0 \\
1.8 \\
1.6 \\
1.2\end{array}$ & $\begin{array}{l}1.2 \\
1.0 \\
1.7 \\
1.5 \\
1.2\end{array}$ & $\begin{array}{l}{ }^{m} \\
1.1 \\
0.9 \\
1.7 \\
1.4 \\
1.1\end{array}$ & $\begin{array}{c}n . / G n \\
1.1 \\
0.8 \\
1.6 \\
1.3 \\
0.9\end{array}$ & $\begin{array}{l}1.0 \\
0.7 \\
1.3 \\
1.2 \\
0.8\end{array}$ & $\begin{array}{l}0.9 \\
0.6 \\
1.1 \\
0.9 \\
0.8\end{array}$ & $\begin{array}{l}0.1 \\
0.1 \\
0.2 \\
0.3 \\
0.2\end{array}$ \\
\hline Mean & & 2.16 & 1.4 & 1.3 & 1.2 & 1.1 & 1.0 & 0.9 & 0.2 \\
\hline Newborn & $\begin{array}{l}1 \\
2 \\
3 \\
4 \\
5\end{array}$ & $\begin{array}{l}0.88 \\
1.60 \\
1.65 \\
2.44 \\
2.56\end{array}$ & $\begin{array}{l}1.1 \\
2.7 \\
1.7 \\
2.9 \\
4.4\end{array}$ & $\begin{array}{l}1.0 \\
2.6 \\
1.7 \\
2.8 \\
4.4\end{array}$ & $\begin{array}{l}1.0 \\
2.5 \\
1.6 \\
2.6 \\
4.1\end{array}$ & $\begin{array}{l}0.9 \\
2.3 \\
1.4 \\
2.5 \\
3.9\end{array}$ & $\begin{array}{l}0.8 \\
1.9 \\
1.2 \\
2.3 \\
3.5\end{array}$ & $\begin{array}{l}0.7 \\
1.3 \\
1.0 \\
1.9 \\
2.6\end{array}$ & $\begin{array}{l}0.2 \\
0.3 \\
0.2 \\
0.4 \\
1.2\end{array}$ \\
\hline Mean & & 1.82 & 2.6 & 2.5 & 2.4 & 2.2 & 1.9 & 1.5 & 0.5 \\
\hline $\begin{array}{l}\text { Hyaline- } \\
\text { membrane }\end{array}$ & $\begin{array}{r}1 \\
2 \\
3 \\
4 \\
5 \\
6 \\
7 \\
8 \\
9 \\
10\end{array}$ & $\begin{array}{l}0.85 \\
1.85 \\
1.95 \\
2.10 \\
2.35 \\
2.38 \\
2.40 \\
2.60 \\
2.80 \\
3.00\end{array}$ & $\begin{array}{l}0.4 \\
0.8 \\
0.4 \\
0.6 \\
0.9 \\
0.2 \\
1.3 \\
1.2 \\
0.3 \\
1.2\end{array}$ & $\begin{array}{l}0.4 \\
0.7 \\
0.4 \\
0.6 \\
0.9 \\
0.2 \\
1.2 \\
1.1 \\
0.3 \\
1.1\end{array}$ & $\begin{array}{l}0.4 \\
0.5 \\
0.3 \\
0.5 \\
0.8 \\
0.2 \\
1.2 \\
1.1 \\
0.2 \\
1.0\end{array}$ & $\begin{array}{l}0.3 \\
0.3 \\
0.2 \\
0.4 \\
0.7 \\
0.2 \\
1.1 \\
1.0 \\
0.2 \\
0.8\end{array}$ & $\begin{array}{l}0.2 \\
0.1 \\
0.1 \\
0.2 \\
0.6 \\
0.2 \\
0.9 \\
0.8 \\
0.1 \\
0.7\end{array}$ & $\begin{array}{l}0.1 \\
0.0 \\
0.1 \\
0.2 \\
0.3 \\
0.1 \\
0.7 \\
0.7 \\
0.0 \\
0.5\end{array}$ & $\begin{array}{l}0.1 \\
0.0 \\
0.0 \\
0.0 \\
0.0 \\
0.0 \\
0.0 \\
0.0 \\
0.0 \\
0.3\end{array}$ \\
\hline Mean & & 2.29 & 0.7 & 0.7 & 0.6 & 0.5 & 0.4 & 0.3 & 0.1 \\
\hline
\end{tabular}

* At autopsy.

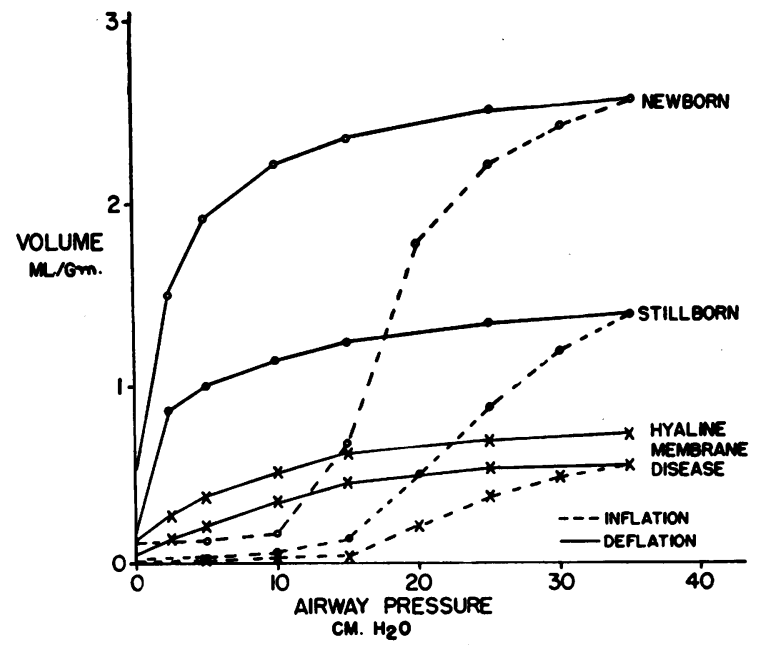

Fig. 3. Volume-Pressure Characteristics

The ordinate refers to gas volume in milliliters per gram of tissue; airway pressure on the abscissa is equivalent to transpulmonary pressure. Four of the lungs with hyaline membrane disease were studied only during deflation and are represented by a separate curve. volume, referring to Figure 4, the transpulmonary pressure would have been about $4 \mathrm{~cm} . \mathrm{H}_{2} \mathrm{O}$, a value not significantly different from the average static end-expiratory esophageal pressure found in healthy, seated young adults (14). Berglund and Karlberg (6) reported that the FRC ranged from 25 to $45 \mathrm{ml}$. in three newborn infants with clinical and X-ray evidence of extensive atelectasis. If the lungs in our study may be accepted as typical of hyaline membrane disease, at least in its final stage, then a significant reduction of FRC is to be expected. Figure 4 shows that the average volume of gas in these lungs, exclusive of the tra-

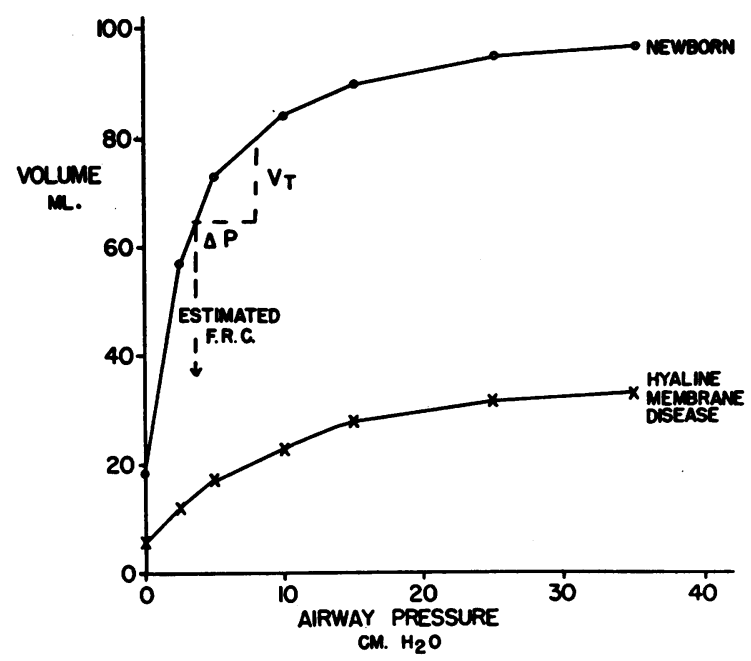

Fig. 4. Volume-Pressure Characteristics

The ordinate refers to total gas volume in milliliters. The estimate of functional residual capacity (FRC) is based on data from Berglund and Karlberg (6). The tidal volume $\left(V_{T}\right)$ is an average value $(15 \mathrm{ml}$.) from data of Karlberg and associates (15). The change in transpulmonary pressure necessary to produce this tidal volume is indicated by $\Delta \mathrm{P}$.

chea and proximal airways, was about $35 \mathrm{ml} .{ }^{1}$ at a peak pressure of $35 \mathrm{~cm} . \mathrm{H}_{2} \mathrm{O}$. For the same pressure, the volume of gas in the newborn lungs was almost $100 \mathrm{ml}$. Over most of the range of pressure studied, a three- to fourfold difference in volume would have been present, so that the FRC, terminally, in the infants with hyaline membrane

1 To test whether an appreciable number of uninflated units of the lungs could have been "forced open," pressure was raised to 60 and $80 \mathrm{~cm} . \mathrm{H}_{2} \mathrm{O}$ in a few preparations. At these levels of pressure there was more extensive inflation of the lungs. The increase in volume, however, was associated with the appearance of leaks through the pleural surface. 
disease would be expected to be around $20 \mathrm{ml}$. (assuming the same transpulmonary pressure for both groups).

\section{Pulmonary compliance}

From Figure 4 the difference in compliance during life between the two sets of lungs could be estimated if data were available on tidal volume and either FRC or its associated transpulmonary pressure. For example, if in each group the tidal volume were about $15 \mathrm{ml}$., a value consistent with the findings of Karlberg and associates (15), and if the end-expiratory pressure were about $4 \mathrm{~cm}$. $\mathrm{H}_{2} \mathrm{O}$, the average values for compliance would have been $3.3 \mathrm{ml}$. per $\mathrm{cm} . \mathrm{H}_{2} \mathrm{O}$ for the newborn infants and only $0.8 \mathrm{ml}$. per $\mathrm{cm} . \mathrm{H}_{2} \mathrm{O}$ for the infants with hyaline membrane disease. ${ }^{2}$ Cook and associates (7) reported a value of $5.2 \pm 0.4 \mathrm{ml}$. per $\mathrm{cm} . \mathrm{H}_{2} \mathrm{O}$ for a group of healthy newborn infants whose weight at birth averaged $3.1 \mathrm{Kg}$. These authors were able to measure compliance in two infants considered to have hyaline membrane disease. At the height of the illness, before recovery began, the values were 0.7 and $1.3 \mathrm{ml}$. per $\mathrm{cm}$. $\mathrm{H}_{2} \mathrm{O}$.

According to our estimates, therefore, the lungs with hyaline membrane disease showed roughly the same magnitude of reduction in FRC and compliance, both values falling to about one-fourth the level of values for the newborn lungs. It is possible, however, that changes in FRC may at times be small relative to the changes in compliance. The reason is that with the appearance of atelectasis, considered an important component of the disease $(16,17)$, the thoracic cage might be expected to resist reduction of its own volume. The increasing elastic resistance of the thorax would then operate as a force distending the lungs, that is, there would be an increase in end-expiratory transpulmonary pressure (pleural pressure would become more subatmospheric). As a result the volume of units of the lungs remaining open

\footnotetext{
2 It is recognized that the slope of the static elastic curve obtained on deflation from a peak distending pressure of $35 \mathrm{~cm} . \mathrm{H}_{2} \mathrm{O}$ is not exactly the same for the next inspiration. Instead, the curve of the next inflation has a lower slope (13). For this reason, the estimates of compliance given here are probably higher than would be found during spontaneous breathing.
}

would enlarge in accordance with their individual volume-pressure characteristics. If these units enlarged sufficiently, the slope of their volumepressure curves, and therefore the slope of the curve for the entire lung, would become depressed.

The means by which the disease affects the elastic behavior of the lungs is not clear. There is no histological evidence that elastic tissue is damaged structurally, or that fibrosis occurs. A change in the surface tension of fluid lining the airways and alveoli has recently been described in this laboratory (18), which offers a basis for the atelectasis that is commonly observed. Whether the hyaline membrane itself acts as a plug completely shutting off sections of the lungs, as suggested by the histologic study of Craig, Fenton and Gitlin (4), or depends for its effect upon changes in surface forces secondary to partial occlusion of the airways or to a combination of these factors, is uncertain. An effort was made to estimate the relative importance of complete and partial plugging in four experiments in the following way: first, volume-pressure measurements were made inflating the lungs with air. The lungs were then freed of air with a method described by von Neergaard (19) in which the lungs were placed in a vacuum jar and the pressure in the jar was lowered to about $15 \mathrm{~mm}$. $\mathrm{Hg}$. Measurements were then repeated substituting saline for air. ${ }^{3}$ Saline minimizes surface forces by substituting a fluid-to-fluid interface for the gas-fluid interface; the pressure needed to distend the lungs is thereby reduced (20). Saline filling was not entirely satisfactory, for in each instance there were leaks through the pleural surface, too widespread to be corrected, that appeared at pressures of about 8 to $10 \mathrm{~cm} . \mathrm{H}_{2} \mathrm{O}$. We have no explanation for this paradox of leaks occurring during saline studies but not during gas studies when higher distending pressures are used. Despite the presence of leaks, however, some of the lungs appeared to fill more completely with fluid than they had with air; areas of the lungs that had not inflated with air at a pressure of $35 \mathrm{~cm} . \mathrm{H}_{2} \mathrm{O}$ now appeared to fill at a pressure of only $10 \mathrm{~cm} \cdot \mathrm{H}_{2} \mathrm{O}$. The evidence suggests that inflation of the lungs may be

\footnotetext{
3 The lungs were submerged in a saline bath according to a technique described by Mead. Whittenberger and Radford (13).
} 
prevented at least in part by forces operating at the gas-fluid interface.

For the interface to resist an inflationary pressure as high as $35 \mathrm{~cm} . \mathrm{H}_{2} \mathrm{O}$, assuming for the moment that no increase in surface tension has occurred, there must be significant narrowing of the airway owing presumably to the presence of hyaline material. An estimate of the degree to which such narrowing may have progressed can be made from the following relationship developed by LaPlace :

$$
\mathrm{P}=\frac{2 \mathrm{~T}}{\mathrm{r}}
$$

where $\mathrm{P}=$ the difference in pressure across the gas-fluid surface, $\mathrm{T}=$ the surface tension, and $\mathbf{r}=$ the radius of curvature of the surface. Normally, nearly all alveolar units are opened by a pressure of $20 \mathrm{~cm} . \mathrm{H}_{2} \mathrm{O}$. In the diseased lungs containing partially blocked units that were not opened by pressures of 35 to $40 \mathrm{~cm} . \mathrm{H}_{2} \mathrm{O}$ (some remained closed at pressures up to $80 \mathrm{~cm} . \mathrm{H}_{2} \mathrm{O}$ ), the radius of curvature of the surface and, therefore, the diameter of the lumen itself must have been reduced to at least half its normal size.

The findings indicate that when hyaline membrane disease is advanced, portions of the lungs will not inflate at transpulmonary pressures as high as $35 \mathrm{~cm} . \mathrm{H}_{2} \mathrm{O}$. At this level of pressure there is a possibility that units already open may be damaged.

\section{SUMMARY AND CONCLUSION}

Comparison was made of virtually static volume-pressure relations of excised lungs obtained from 10 infants with hyaline membrane disease, five newborn infants dying from other causes, and five stillborn infants. To eliminate the influence of size on these measurements, volume was expressed as milliliters of gas per gram of tissue. Special emphasis was given to the volume-pressure relations during deflation from a peak airway pressure of $35 \mathrm{~cm} . \mathrm{H}_{2} \mathrm{O}$. At all pressures the lungs with hyaline membranes contained less gas per unit of weight than the control lungs; in addition, the slope of their entire volume-pressure curve was depressed. From these volume-pressure relations estimates were made of the magnitude of differences in FRC and compliance that might have been present during life. The differences compared closely with direct measurements made by other investigators. The low compliance in membrane-containing lungs was thought to be due to a reduction in number of units participating in ventilation. The relative importance of changes in surface forces that might lead either to a collapse of units or to increased resistance to inflationary pressures and of mechanical plugging could not be determined from these studies.

\section{ACKNOWLEDGMENTS}

The authors are grateful to Dr. Kurt Benirschke and Dr. John Craig for permission to study lungs obtained at autopsy, and to Dr. Jere Mead and Dr. James L. Whittenberger for their advice during this study.

\section{REFERENCES}

1. Tran-Dinh-De, and Anderson, G. W. Hyaline-like membranes associated with diseases of the newborn lungs: A review of the literature. Obstet. gynec. Surv. 1953, 8, 1.

2. Curtis, P. Hyaline membrane disease. J. Pediat. 1957, 51, 726.

3. Behrle, F. C., Gibson, D. M., and Miller, H. C. Role of hyaline membranes, blood, exudate, edema fluid and amniotic sac contents in preventing expansion of the lungs of newborn infants. Pediatrics 1951, 7, 782.

4. Craig, J. M., Fenton, K., and Gitlin, D. Obstructive factors in the pulmonary hyaline membrane syndrome in asphyxia of the newborn. Pediatrics 1958, 22, 847.

5. Gruenwald, P. in Proc. Special Committee on Infant Mortality, Panel Discussion, H. Abramson, Ed. N. Y. St. J. Med. 1958, 58, 372.

6. Berglund, G., and Karlberg, P. Determination of the functional residual capacity in newborn infants. Acta paediat. (Uppsala) 1956, 45, 541.

7. Cook, C. D., Sutherland, J. M., Segal, S., Cherry, R. B., Mead, J., McIlroy, M. B., and Smith, C. A. Studies of respiratory physiology in the newborn infant. III. Measurements of mechanics of respiration. J. clin. Invest. 1957, 36, 440.

8. Miller, W. S. The Lung, 2nd ed. Springfield, Ill., Charles C Thomas, 1950. The author quotes Waters (1860) and Wilmart (1897), p. 4.

9. McIlroy, M. B., and Christie, R. V. A post-mortem study of the viscoelastic properties of the lungs in emphysema. Thorax 1952, 7, 295.

10. Engel, S. The Child's Lung: Developmental Anatomy, Physiology and Pathology. London, Edward Arnold and Co., 1947, Chapter 17.

11. Gribetz, I., Avery, M. E., and Frank, N. R. Unpublished data. 
12. Avery, M. E., Frank, N. R., and Gribetz, I. The inflationary force produced by pulmonary vascular distention in excised lungs. The possible relation of this force to that needed to inflate the lungs at birth. J. clin. Invest. 1959, 38, 456.

13. Mead, J., Whittenberger, J. L., and Radford, E. P., $\mathrm{Jr}$. Surface tension as a factor in pulmonary volume-pressure hysteresis. J. appl. Physiol. 1957, 10, 191.

14. Frank, N. R., Mead, J., and Ferris, B. G., Jr. The mechanical behavior of the lungs in healthy elderly persons. J. clin. Invest. 1957, 36, 1680.

15. Karlberg, P., Cook, C. D., O’Brien, D., Cherry, R. B., and Smith, C. A. Studies of respiratory physiology in the newborn infant. II. Observations during and after respiratory distress. Acta paediat. (Uppsala) 1954, 43, Suppl. 100, 397.
16. Potter, E.'L. Pathology of the Fetus and Newborn. Chicago, Yearbook Publishers, 1952, Chapter 15.

17. Gruenwald, P. The significance of pulmonary hyaline membranes in newborn infants. J. Amer. med. Ass. 1958, 166, 621.

18. Avery, M. E., and Mead, J. Surface properties in relation to atelectasis and hyaline membrane disease. A.M.A. Amer. J. Dis. Child. 1959, 97, 517.

19. Neergaard, K. von. Neue Auffassungen über einen Grundbegriff der Atemmechanik. Die Retraktionskraft der Lunge, abhängig von der Oberflächenspannung in den Alveolen. Z. ges. exp. Med. 1929, 66, 373.

20. Radford, E. P., Jr. Recent studies of mechanical properties of mammalian lungs in Tissue Elasticity, J. W. Remington, Ed. Washington, D. C. American Physiological Society, 1957, p. 177. 